\title{
NIEDOSZŁA ABDYKACJA CESARZA SHŌWA PO II WOJNIE ŚWIATOWEJ
}

Jakub Polit

Uniwersytet Jagielloński w Krakowie

\author{
ABSTRACT \\ EMPEROR'S SHŌWA POSSIBLE (BUT UNREALIZED) ABDICATION \\ AFTER WORLD WAR II
}

At the end of World War II, the Allies were almost unanimous that Japanese Shōwa Emperor (known as Hirohito) had to be tried as a war criminal and the imperial institution, seen as the foundation of Japanese militarism, be abolished. The final decision was left to general Douglas MacArthur, who carried the responsibility for occupation policies in Japan. The general, especially after the first meeting with the Emperor (27 Sept. 1945), found the throne as "a symbol which unites all Japanese" and a key to the success of the occupation reforms. He telegraphed Washington that no evidence had been discovered that would implicate the Emperor in war crimes. The British occupation authorities in Japan (sir Alvary Gascoigne, George Sansom) fully shared this opinion. Hirohito was not put on trial, but in 1948, when IMFTE sentenced to death seven former ministers and generals, there were rumours that he was seriously considering whether to abdicate. MacArthur, believing that such a step would be politically disastrous, on $12^{\text {th }}$ November 1948 intervened confidentially and successfully via prime minister Yoshida Shigeru and director of the imperial Household agency Tajima Michiji. The last abdication rumours appeared in October 1951, after the peace treaty was signed. But the Emperor, bound by a promise given to MacArthur, remained on the throne.

Key words: allied occupation of Japan, Japanese monarchy, emperor's Shōwa would-be abdication.

Słowa kluczowe: aliancka okupacja Japonii, japońska monarchia, niedoszła abdykacja cesarza Hirohito.

Latem 1945 roku wydawało się oczywiste, że los monarchii japońskiej jest przesądzony. Walczącym po stronie Osi europejskim władcom nie udało się wszak uratować koron, choć w odwróceniu sojuszów przez swe kraje odegrali nieraz wybitną rolę. Tymczasem w wypadku Kraju Kwitnącej Wiśni panujący nie tylko nie był postrzegany jako przeciwnik rządzącej dyktatury, ale zdawał się stanowić jej ostoję 
i kwintesencję. Specyficzna forma totalitaryzmu japońskiego nie dopuściła bowiem do przejęcia władzy przez jednego, charyzmatycznego dyktatora; na czele wojennego reżimu stał przez cały czas - jak to ujął sławny historyk Alan J.P. Taylor - ,anonimowy warlord"'. W sytuacji gdy premier Tōjō Hideki, z racji generalskiej rangi uważany za granicą za ,japońskiego Hitlera”, w lipcu 1944 roku postradał stanowisko ku wyraźnemu zaskoczeniu aliantów, cały gniew opinii publicznej koalicji skoncentrowany został na cesarzu (jap. tennō) Shōwa, powszechnie znanym jako Hirohito. Łatwo rozpoznawalny, choć w istocie zupełnie nieznany jako człowiek, stanowił on czytelny symbol krwawego i okrutnego reżimu. Brytyjski charge d'affaires John Balfour raportował z Waszyngtonu:

Niemal wszyscy tutaj [...] wołają o usunięcie cesarza, ocenianego jako symbol japońskiego militaryzmu. Wrzawa podnoszona jest głównie dlatego, iż nie licząc swego powszechnie znanego białego wierzchowca, jest on jedynym Japończykiem, którego imię mówi cokolwiek mieszkańcom tego kraju ${ }^{2}$.

Dokonany latem 1945 roku sondaż wykazał, że 33\% Amerykanów domagało się stracenia Hirohito, 20\% - uwięzienia lub wygnania, 16\% oddawało decyzje w ręce sądu, a tylko 3\% popierało wykorzystanie tennō w interesie zwycięzców ${ }^{3}$. Nastroje Brytyjczyków nie były wiele łagodniejsze, w Australii zaś (jedynym kraju z europejską genezą, który niedawno liczył się z japońską inwazją) chęć odwetu przewyższała bodaj amerykańską4.

Japończycy, którzy z pozostawienia cesarza na tronie usiłowali uczynić główny warunek kapitulacji zapowiedzianej przez zwycięzców jako bezwarunkowa, mogli w tej sytuacji wytargować niewiele. Jest prawdą, że w kluczowej pod wielu względami nocie alianckiej z 11 sierpnia 1945 roku znalazło się sformułowanie, iż „od momentu kapitulacji władza cesarza i rządu japońskiego będzie podporządkowana naczelnemu dowódcy wojsk sojuszniczych"'. Widziano w tym, nie do końca niesłusznie, zawoalowaną półobietnicę, skoro „instytucja, która miała być podporząd-

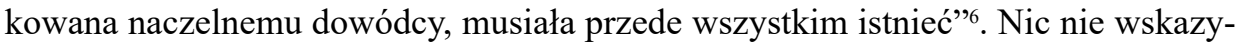
wało jednak, by miała istnieć zbyt długo, gdyby zaś nawet przetrwać miał tron, to na pewno niezasiadający na nim władca. Pod koniec września 1945 roku Kongres USA - którego rezolucja nie była co prawda wiążąca dla rządu - oznajmił, że „polityką Stanów Zjednoczonych jest postawienie przed sądem cesarza Hirohito jako

1 Tytuł odpowiedniego rozdziału w znanej książce Taylora o sześciu przywódcach mocarstw czasu II wojny światowej (A.J.P. Taylor, The War Lords, London 1979, s. 157) brzmi War Lord Anonymous.

2 Charge d'affaires Balfour do Foreign Office, 11 VIII 1945, The National Archives, London [dalej TNA], FO 371/46453/F5035/No5541.

3 Memorandum J.W. Ballantine'a, 6 VIII 1945, Foreign Relations of the United States 1945 [dalej FRUS], vol. VI, Washington 1969, s. 586-590; K. Starecka, Geneza systemu cesarza-symbolu [w:] Z chryzantema w herbie. W 10. rocznicę wizyty ich Cesarskich Mości, Cesarza i Cesarzowej Japonii na Uniwersytecie Warszawskim, red. U. Mach-Bryson, A. Zalewska, Warszawa 2014, s. 53-57.

4 Znamienna jest tu australijska reakcja na kapitulację Japonii (Japanese Surrender - Imperial Rescript to Japanese People, opinie zebrane w Foreign Office, 16 VIII 1946, TNA, FO 371/46453/ F5160/630/23).

5 Nota aliancka z 11 sierpnia 1945, FRUS 1945, vol. VI, s. 628.

6 W. Góralski, Stany Zjednoczone - Japonia 1945-1972, Warszawa 1976, s. 48. 
wojennego zbrodniarza"7. Rząd sowiecki, którego przedstawiciele odgrywali hałaśliwą rolę w Radzie Sojuszniczej, doradzającej w Tokio alianckiemu głównodowodzącemu Douglasowi MacArthurowi, oraz w skupiającej cztery mocarstwa waszyngtońskiej Komisji Dalekowschodniej (Far Eastern Commission), gorliwie forsował takie właśnie rozwiązanie.

W tej sytuacji abdykacja Hirohito z pozoru wydawała się najprostszą i najbardziej skuteczną drogą ratowania monarchii i dynastii. Zdawała się ona tym bardziej naturalna, że w dziejach Japonii więcej niż połowa cesarzy - przynajmniej jeśli chodzi o władców historycznych - ustąpiła $\mathrm{z}$ tronu dobrowolnie lub przymusowo ${ }^{8}$.

Sam cesarz Shōwa nie kierował się z pewnością względami własnego bezpieczeństwa, lecz uczuciami patriotycznymi. Odegrał kluczową rolę w przeforsowaniu decyzji o kapitulacji, skutecznie przełamując sprzeciw wojskowych, domagających się uzyskania bardziej precyzyjnych gwarancji dla monarchii i dynastii甲. Ponieważ zwycięzcy jasno zapowiadali postawienie przywódców japońskich przed sądem, władca na serio liczył się z procesem, a nawet egzekucją. 6 września 1945 roku napisał list do dwunastoletniego wówczas następcy tronu, ewakuowanego w czasie nalotów do Nikkō (sam stanowczo odmówił opuszczenia Tokio). Dokument zawierał „parę słów o przyczynach naszej klęski” i wyjaśniał: „,nasi ludzie pokładali zbyt wiele zaufania w Imperium a mieli w pogardzie Anglię i Amerykę. Nasi wojskowi kładli zbyt wielki nacisk na ducha [bojowego] i zapomnieli o technice. [...] Przełykając łzy, usiłowałem ratować naród japoński przed zagładą" ${ }^{10}$. Zważywszy na wiek adresata oraz okoliczności (w normalnych warunkach ojciec liczyć mógłby wszak na relatywnie szybkie spotkanie z synem), niezwykły ten dokument miał wszelkie cechy przeznaczonego dla potomności i historii listu pożegnalnego.

Tennō, czującego się konstytucyjnym zwierzchnikiem rządu oraz sił zbrojnych, przygnębiała wizja procesu polityków i wojskowych, którzy (przynajmniej formalnie) wykonywali tylko jego rozkazy. Już 29 sierpnia minister środka (zwany na Zachodzie kanclerzem tajnej pieczęci) Kidō Kōichi zanotował w diariuszu, że wizja ta „była dla niego [cesarza - J.P.] nie do zniesienia i że wolałby raczej wziąć na siebie całą winę, rezygnując z tronu, niż wydać ich aliantom"'

Przeciwko abdykacji przemawiały wszakże przynajmniej dwa ważne względy. Kidō, mający w tej kwestii zdecydowane poparcie większości dworu (przede wszystkim wielkiego szambelana Fujity Isanoriego, sprawującego swą godność od 1944 roku do maja 1946, oraz ministra dworu cesarskiego Ishiwaty Sotarō), był przekonany, że sama abdykacja nie wystarczy aliantom, za to „może ostatecznie zniszczyć

7 Cyt. za: D.C. James, The Years of MacArthur, vol. III: Triumph and Disaster, 1945-1964, Boston 1985, s. 105.

8 Od rezygnacji cesarzowej Kōgyoku w 645 r. aż do abdykacji cesarza Kōkaku w 1817 r. z tronu zrezygnowało dwie trzecie cesarzy (B.-A. Shillony, The Enigma of the Emperors. Sacred Subservience in Japanese History, Folkestone 2005, s. 49).

9 Przedstawia to (nadal w wielu aspektach niezastąpiona) monografia: R.J.C. Butow, Japan's Decision to Surrender, Stanford, Calif. 1954.

10 Cyt. za: N. Kaw amura, Emperor Hirohito and the Pacific War, Seattle-London 2015, s. 183.

11 Cyt. za: S.S. Large, Emperor Hirohito and Shōwa Japan. A Political Biography, LondonNew York 1992, s. 132. 
podstawy rodziny cesarskiej sprawiając, iż w rezultacie górę wezmą zwolennicy republikańskiej formy rządów”'2. Pogląd ten podzielała zdecydowana większość panującej rodziny, w tym trzej cesarscy bracia, książęta Chichibu, Takamatsu i Mikasa, będący z natury rzeczy kandydatami na regentów przy nieletnim (ur. 1933) Akihito. Także sędziwy premier admirał Suzuki Kantarō stwierdzał, że „w obecnej, chaotycznej sytuacji nikt inny nie będzie zdolny do odbudowy Japonii. [Cesarz] nie powinien myśleć o abdykacji. [...] Jego Cesarska Mość winien poczynić trudny wybór i znosić trudy wraz ze swym ludem. Będzie musiał ponieść odpowiedzialność za wojnę nadal pozostając na tronie"13.

Drugi powód był równie ważki. Obowiązująca formalnie nadal (acz pod wieloma względami naruszana) konstytucja Meiji, traktowana przez Hirohito z religijną niemal czcią, w ogóle nie przewidywała możliwości abdykacji panującego.

Tymczasem los cesarza i monarchii zależał w ogromnej mierze od jednego człowieka: alianckiego wielkorządcy generała MacArthura, wyposażonego w olbrzymią i niemal nieograniczoną władzę na Wyspach Japońskich. Prócz zwierzchnictwa nad wojskami okupacyjnymi (obok amerykańskich należały do nich także znaczne oddziały Wspólnoty Brytyjskiej, stacjonujące na wyspie Shikoku i zachodnich krańcach Honshū) posiadał on atrybuty swoistego suwerena - na przykład akredytowani byli przy nim zagraniczni dyplomaci. Grupująca przedstawicieli USA, Wielkiej Brytanii, Chin i Sowietów wspomniana już tokijska Rada Sojusznicza wobec jego decyzji miała, w najostrzejszym kontraście do podobnej instytucji w Niemczech, jedynie głos doradczy. Przekazane generałowi z Waszyngtonu dość ogólnikowe instrukcje nie były dla japońskiej monarchii pomyślne. Ich kluczowe sformułowanie brzmiało: „Wytyczną polityki amerykańskiej jest wykorzystanie, nie wspieranie, obecnej formy rządu w Japonii" ${ }^{14}$.

Stosunek MacArthura do japońskiej monarchii był w owym czasie zagadką nie tylko dla Japończyków. Sześćdziesięcioletni w 1945 roku „zwycięzca Pacyfiku”, spędziwszy znaczną część życia na Dalekim Wschodzie, jako jeden z bardzo niewielu amerykańskich wojskowych znał wprawdzie Japonię z autopsji: w 1905 roku przedstawiony został ojcu Hirohito, późniejszemu cesarzowi Taishō. Stan wiedzy generała na temat tego kraju jest przedmiotem kontrowersji; najbardziej sceptyczni badacze posuwają się do twierdzeń, że był on nader nikły ${ }^{15}$, ale nawet w tym wypadku przewyższałby informacje posiadane przez większość generalicji oraz polityków USA. MacArthur był bodaj jedynym amerykańskim generałem znanym zwykłym Japończykom już w czasie wojny. Istnieją poszlaki, że nigdy nie uważał Hirohito ani za jej sprawcę, ani za krwiożerczego tyrana, ale poglądy takie - jeśli artykułowane były rzeczywiście - nie wydostawały się poza wąskie grono najbliższych mu osób ${ }^{16}$.

12 Cyt. za: ibidem.

13 Cyt. za: N. Kawamura, op. cit., s. 191.

14 Cyt. za: Political Reorientation of Japan. September 1945 to September 1948, by the Supreme Commander of Allied Powers, Government Section, 1949, Westport Conn. 1970, vol. II, s. 424.

15 Ów nurt krytyczny reprezentuje przede wszystkim Michael Schaller (Douglas MacArthur. The Far Eastern General, Oxford 1989).

16 D.C. James, The Years of MacArthur, vol. II: 1941-1945, Boston 1975, s. 779. 
Dnia 11 września żandarmeria aliancka aresztowała pierwszych Japończyków figurujących na (nieznanej wyspiarzom w sensie personaliów) liście zbrodniarzy wojennych. Wśród zatrzymanych, co było szokiem dla dworu, znajdował się kuzyn cesarza, książę Nashimoto Morimasa. Tuż wcześniej inny cesarski krewniak, będący premierem książę Higashikuni Naruhiko (bezprecedensowe mianowanie go szefem rządu miało przydać majestatu gabinetowi, wzywającemu armię do kapitulacji) podjął próbę obrony cesarza. Zapytany w wywiadzie prasowym o odpowiedzialność monarchy za decyzje z 1941 roku (w tym atak na Pearl Harbor), wyjaśnił, że według konstytucji tennō w decyzjach gabinetu nie uczestniczy, o planach uderzenia na Hawaje wiedział „niewiele” oraz że „,esarz nie ponosi żadnej odpowiedzialności za wojnę"17.

Sam cesarz Shōwa popełnił w tym czasie wyraźny błąd wizerunkowy, udzielając 25 września bezprecedensowego wywiadu prasowego magazynowi „New York Times". Słowa, że to aresztowany premier Tōjō odpowiadał za rozpoczęcie wojny z USA przed jej formalnym wypowiedzeniem, były co najmniej niezręczne (za ten akurat fakt Tōjōnie ponosił winy), sugerowały ponadto, że cesarzem kieruje głównie troska o osobiste przetrwanie ${ }^{18}$.

Sytuację zmieniło jednak ogromnie rychłe (z 27 września) spotkanie władcy z MacArthurem. Jego przebieg, a zwłaszcza złożenie na samym początku przez tennō oświadczenia, iż tylko on ponosi odpowiedzialność za decyzje czasu wojny, próbowano potem podważać jako stworzoną ex post deklarację propagandową; świadectwa archiwalne potwierdzają wszakże, że wypowiedź taka, która zaskoczyła „Zwycięzcę Pacyfiku” i zaimponowała mu, padła naprawdę ${ }^{19}$. Brak jakiegokolwiek protokołu pozwala na całe spektrum domysłów, od twierdzeń, że generał wszystkie istotne decyzje podjął już wcześniej, po przekonanie, że „zasady okupacyjnej polityki zostały sformułowane w czasie jedenastu spotkań między cesarzem a generałem MacArthurem"20. Tak czy inaczej, otoczenie władcy było poruszone; wedle diariusza szambelana (potem Wielkiego Szambelana, czyli marszałka dworu) Irie Sukemasy MacArthur wywarł „niezmiernie korzystne wrażenie” na osobistościach dworu ${ }^{21}$.

Odcięty od zagranicznych kontaktów Hirohito podjął tymczasem próbę nawiązania kontaktu z ośrodkiem zagranicznym, z którym japońska rodzina cesarska utrzymywała przed wojną najżywsze kontakty, a mianowicie z londyńskim Dworem Świętego Jakuba. Oba panujące rody łączyły od czasów cesarza Meiji zażyłe i przynajmniej pozornie serdeczne stosunki, najbardziej ożywione podczas sojuszu japońsko-brytyjskiego w latach 1902-1922. Ich ucieleśnieniem pozostawał młodszy o rok brat cesarza Shōwa, książę Chichibu (Yasuhito). Uważany za najzdolniejszą i najbardziej

17 Cyt. za: S.S. Large, op. cit., s. 144.

18 G. Okubo, The Problem of the Emperor System in Postwar Japan, Tokyo 1948, s. 10.

19 I. Hata, Hirohito. The Shōwa Emperor in War and Peace, Folkestone 2007, s. 186 (praca nie jest biografią, dotyczy kluczowych decyzji podjętych przez władcę); K. Matsumoto, J. Shōji, Critquing Herbert Bix's "Hirohito”, ,Japan Echo” 2002, vol. XXIX, No. 6 (December), s. 65.

20 I. Hata, The Occupation of Japan, 1945-1952 [w:] The American Military and the Far East, ed. J.C. Dix on, Colorado Springs 1980, s. 107.

${ }_{21}$ S.S. Large, op. cit., s. 136. 
tajemniczą postać dynastii, ożeniony z Matsudairą Setsuko, córką dyplomaty anglofila, wykształcony w Oksfordzie, pozujący na sportsmena i bon vivanta (wszystkie te cechy zdecydowanie różniły go od cesarza), był Chichibu patronem brytyjskiego Japan Society i, wraz z uroczą żoną, częstym gościem arystokratycznych imprez nad Tamizą. W latach 30. postrzegano go jako co najmniej przelotnego sympatyka totalitarnych tendencji w armii, czemu jednak raczej przeczyło jego zachowanie podczas sławnej próby radykalnego przewrotu w Tokio 26-29 lutego 1936 roku i późniejsze naciski na brata w celu zakończenia wojny ${ }^{22}$. Choć od lat 30. poważnie chorował na gruźlicę, enigmatyczny książę, a także jego elokwentna małżonka brani byli w Londynie pod uwagę już to jako alternatywa dla cesarza, już to jako kanał porozumienia z nim. Jeszcze w czasie trwania wojny sir Paul Butler, doradca Foreign Office oraz przedstawiciel Londynu w waszyngtońskim Institute of Pacific Relations, wywołał swoisty skandal, oznajmiając, że „,nie jest prawdopodobne, aby jakaś alternatywa dla systemu monarchicznego pod obecnym cesarzem lub jakimś innym członkiem jego rodziny była w stanie stać się źródłem stabilizacji zasadniczej, by kraj nie popadł w chaos podczas nadchodzącego kryzysu"23. Tajemnicą poliszynela (choć wówczas niekoniecznie znaną Japończykom) było, iż poglądy te podziela wielu pracowników Foreign Office, jak ostatni przed wojną ambasador w Tokio sir Robert Craigie czy sir George Sansom, wówczas brytyjski przedstawiciel w międzyalianckiej Far Eastern Commission, uważany za jednego z największych japonistów w skali światowejej ${ }^{24}$.

W styczniu 1946 roku Sansom pojawił się w Tokio. Matsudaira Yasumasa, minister dworu cesarskiego, powiadomił go wówczas, że cesarz chciałby się z nim spotkać „na prywatnej audiencji, bez tłumacza czy szambelana”. Choć rząd japoński (na jego czele stał już Shidehara Kijūrō, o którym będzie jeszcze mowa) nie krył zainteresowania spotkaniem, Sansom odmówił (biadając w diariuszu: „,po raz pierwszy odrzuciłem zaproszenie cesarza!"25). Jako oficjalnemu reprezentantowi Londynu, członkowi międzynarodowej alianckiej komisji, nie wypadało mu fraternizować się z osobistością oskarżaną o zbrodnie wojenne. Mimo to po trzech dniach (29 stycznia) Matsudaira doręczył mu - niepodpisany - list dyktowany przez tennō, a przeznaczony, mimo skierowanych do Sansoma życzeń pomyślnego pobytu w Japonii, w rzeczy samej do brytyjskiej rodziny królewskiej. Jego zasadniczy fragment brzmiał:

Położyłem swój podpis pod deklaracją o wypowiedzeniu wojny z głębokim bólem w sercu, raz po raz powtarzając ówczesnemu premierowi, generałowi Tōjō, że wobec pamięci o szczęś-

22 O nader niejasnej roli księcia w czasie przewrotu w 1936 r. pisał - nie dochodząc do rozstrzygających konkluzji - znakomity izraelski historyk Ben-Ami Shillony (Prince Chichibu and the February 1936 Rebellion, „Princeton Papers in East Asian Studies” 1972, No. 1 (August), s. 123-144).

23 Butler cytowany w: Halifax do FO, 1 II 1945, TNA., FO 371/46444/F714/327/23/805.

24 R. Craigie, Behind the Japanese Mask, London 1946, s. 167 (książka byłego ambasadora napisana została jeszcze w czasie wojny); dokumenty wyrażające poglądy Sansoma na ten temat znajdują się w TNA, FO 371/46447/F4605/364/623.

25 K. Sansom, Sir George Sansom and Japan. Memoir, Tallahassee Florida 1972, s. 153. Są to fragmenty zapisków Sansoma, opublikowane przez jego żonę; odpowiednia notatka pochodzi z 25 I 1946. 
liwych dniach, jakie przeżyłem w Angliii ${ }^{26}$, jestem zmuszony to uczynić z ogromnym żalem i niechęcią.

Głęboko pragnę skrupulatnie wykonywać postanowienia Deklaracji Poczdamskiej, podejmując wszelkie wysiłki dla budowy lepszego narodu, oddanego pokojowi i demokracji. Mogę tylko szczerze wierzyć, że pewnego dnia w przyszłości przywrócimy stosunki dyplomatyczne między naszymi zasługującymi na szacunek krajami i odbudujemy dawną przyjaźń.

Korzystając z obecnej okazji, pragnę przesłać najlepsze życzenia pomyślności dla Rodziny Królewskiej oraz dla przyszłości narodu brytyjskiego ${ }^{27}$.

Przesłanie wywarło wrażenie w Foreign Office, w którym uznano, że Sansom miał rację, odmawiając spotkania, ale miał także rację, żałując tego, gdyż ,byłaby to znacząca okazja”. L.H. Foulds (Far Eastern Department) zauważył, że „gdyby Dom Cesarski przekształcił się w prawdziwą monarchię konstytucyjną na wzór brytyjski, jego trwanie służyłoby naszym interesom" i że Japończyków należy - byle nieoficjalnie, a więc ustnie - powiadomić, iż przesłanie zostało przyjęte. Sterndale Bennett dodał, że Sansom powinien zdać z niego relację królowi Jerzemu VI (po którego prawicy na pokoronacyjnym bankiecie zasiadał książę Chichibu) ${ }^{28}$.

Dodać można, iż dokładnie w dniu otrzymania cesarskiego przesłania Sansom złożył wizytę MacArthurowi, uznając go za „,wielkiego człowieka, nie tylko jako generała, ale także męża stanu”. Pompatyczny styl bycia rozmówcy, dla wielu irytujący, miał na celu, zanotował, ukrycie wrodzonej nieśmiałości „zwycięzcy Pacyfiku” (rzec trzeba, że obie żony ,amerykańskiego Cezara” uznałyby ową uwagę za trafiającą w samo sedno). Przy okazji Anglik odnotował kilka uwag swego interlokutora na temat spotkania $\mathrm{z}$ cesarzem. „W obecnej sytuacji nie było dla niego [MacArthura] możliwe, aby przedstawił się jako pierwszy; zamiast tego cesarz, wykazując wielki rozsądek oraz takt, przybył do niego. [...] MacArthur szanuje go i lubi”"29.

Szczyt Hirohito-MacArthur sam w sobie nie rozwiązywał jednak sprawy abdykacji. ,Zwycięzca Pacyfiku” nie udzielił japońskiemu władcy żadnych obietnic (choć trudno zaprzeczyć, że rodzajem obietnicy był sam nastrój spotkania). Dwór nie mógł także zakładać, że generał ma w sprawie władcy ostatnie słowo.

Premier książę Higashikuni (teść cesarskiej córki, księżniczki Teru) uważał, jak już wspomniano, że monarcha nie był odpowiedzialny za wojnę. Niemniej wielu członków jego rządu mniemało, iż tennō ponosił jednak ,,wobec ludzi i bogów” odpowiedzialność moralną, co najdobitniej artykułował książę Konoe Fumimaro. Potomek starożytnego rodu Fujiwara, o majestacie niemal równym cesarskiemu, w latach 1937-1941 trzykrotnie zasiadał w fotelu premiera. Szybko zrozumiawszy, że

26 Chodzi o wizytę Hirohito w Anglii i Szkocji w maju-czerwcu 1921; na jej temat por.: I. Nish, Crown Prince Hirohito in Britain, May 1921 [w:] Britain \& Japan. Biographical Portraits, ed. I. Nish, Folkestone, Kent 1997, s. 205-215; J. Polit, Admirat Hirohito i Wielka Brytania [w:] Od Port Artur do Port Stanley. Z dziejów konfliktów morskich wXX stuleciu, red. R. Kochanowski, J. Jastrzębski, Oświęcim 2016, s. 130-136.

27 „Przekład Przesłania podyktowanego przez cesarza Japonii panu Matsudairze”, 29 I 1946, TNA, FO 371/54286/F3512/556/23.

28 Notatki (minutes) Fouldsa (27 II 1946) i Bennetta (6 III 1946) pod depeszą Sansoma, ibidem.

29 Notatka Sansoma z 29 I 1946 [w:] K. Sansom, op. cit., s. 157. 
wojna jest nie do wygrania, odegrał znaczną rolę w grupie osobistości prącej do jej zakończenia, starając się inspirować w tym duchu także Hirohito. Pozycja, ambicja oraz wysokie mniemanie o własnych talentach predysponowały go, przynajmniej we własnej opinii, do odegrania czołowej roli w powojennej Japonii.

5 i 17 października Konoe udzielił wywiadu prasowego, oznajmiając, że pożądanym rozwiązaniem byłaby abdykacja cesarza i jego wyjazd do jednego z klasztorów w Kioto; posunął się wręcz do wyboru konkretnego monasteru (Ninnaji) i dokonania jego inspekcji. Z przeprowadzonej dzień wcześniej rozmowy z MacArthurem wyniósł wrażenie - w znacznej mierze na skutek niezręczności tłumacza - że aliancki wielkorządca zamierza powierzyć mu przygotowanie projektu nowej konstytucji (w istocie generał pytał tylko o zmiany w aktualnym rządzie) ${ }^{30}$. Naprawdę „zwycięzca Pacyfiku" był zwolennikiem nie ewolucji, lecz swoistej rewolucji ustrojowej, choć nie obejmowała ona zniesienia monarchii. Dosłownie kilka godzin po spotkaniu z Konoem polecił opublikować sławny Bill o Prawach (Civil Liberties Directive), ogłaszający wolność słowa, prasy i zgromadzeń oraz zezwalający na swobodne krytykowanie cesarza. Dokument spowodował przyspieszoną dymisję efemerycznego gabinetu Higashikuniego, który w oczach władz okupacyjnych zwyczajnie odegrał już swą rolę, ograniczoną do przeprowadzenia kapitulacji. 9 października premierem został Shidehara Kijūrō, powszechnie ceniony przez Anglosasów dawny liberalny minister spraw zagranicznych z lat 20. Za to 12 listopada Higashikuni, jako „moralnie odpowiedzialny za brak odwagi [właściwego] doradzenia Tronowi w okresie ogromnej wagi dla państwa", zrzekł się wszystkich tytułów, w tym godności księcia krwi, ogłaszając się „zwyczajnym poddanym”’”.

Konoe, czujący się już współtwórcą nowego ustroju i faktycznym regentem cesarstwa, z przerażeniem ujrzał, że zwycięzcy widzą w nim kandydata nie na premiera, ale na jednego z czołowych oskarżonych w procesie zbrodniarzy wojennych przed Międzynarodowym Trybunałem Wojskowym dla Dalekiego Wschodu (ang. skrót IMFTE). Także Shidehara postrzegał go jako grabarza przedwojennych rządów parlamentarnych. 16 grudnia książę popełnił samobójstwo. Jego polityczne lawiranctwo, a przede wszystkim czytelna chęć pozbycia się swego cesarskiego dobroczyńcy wywarły fatalne wrażenie na aliantach, w tym na sztabie MacArthura. Jeden z jego oficerów porównał Konoego do „szczura, który dla własnego ocalenia jest całkowicie gotów sprzedać każdego, posuwając się wręcz do nazwania swego pana, cesarza, «głównym zbrodniarzem wojennym»" 32 .

Niemal jednocześnie ze śmiercią Konoego przyszła wieść o aresztowaniu Kido Kōichiego, który tuż wcześniej, 10 grudnia, zdołał uzyskać audiencję w pałacu.

30 D.M. Hellegers, The Konoye Affair [w:] The Occupation of Japan. Impact of Legal Reform, ed. L.H. Redford, Norfolk 1978, s. 167-168; J.K. Emmerson, Japanese Thread. A Life in U.S. Foreign Service, New York 1978, s. 265; Y. Oka, Konoe Fumimaro. A Political Biography, Lanham 1992, s. 217-219.

31 Prince Higashikuni Determined, „Nippon Times”, 12 XI 1945 (stąd cytaty); MacDermott do Foreign Office, 12 XI 1945, TNA, FO 371/46431/F117683/4/23.

32 Notatka Gascoigne'a z 9 XI 1945 pod protokołem przesłuchania Konoego, TNA, FO 371/54286/ F556/556/23. 
Apelował do władcy, by pozostał na tronie co najmniej do chwili odbudowy kraju jako „pokojowego członka wspólnoty międzynarodowej”, czyli do zawarcia traktatu pokojowego. „Jeśli - przekonywał - Wasza Cesarska Mość nalega na poniesienie jakiegoś rodzaju odpowiedzialności, to na Waszej Cesarskiej Mości spoczywa ciężka odpowiedzialność doprowadzenia Japonii do tego etapu"33. Czy jednak przewodzić Japonii mógł ktoś, kto lada chwila mógł sam zostać aresztowany? Powszechnie uznawano, że „aresztowanie [księcia] Nashimoto, ukazujące, iż rodzina cesarska nie jest nietykalna, a także najbliższych doradców cesarza, Kido i Konoego, wznowiło dyskusję o możliwości abdykacji cesarza"34.

Licząc się z procesem, a może i z ewentualnością samobójstwa, Hirohito podyktował 18, 20, 22 marca oraz (dwukrotnie) 8 kwietnia 1946 roku dokument, znany jako „Ośmiogodzinny Monolog cesarza Shōwa” (Shōwa tennō dokuhaku roku). Ukryty i ujawniony (pośmiertnie) dopiero w latach 90 . w osobistych papierach jednego ze stenografów, Terasakiego Hidenariego, mógł być próbą zebrania materiałów mających posłużyć mowie obrończej przed sądem. W większej mierze stanowił jednak przekaz dla potomności, mający ocalić cesarską wersję wydarzeń. Mimo nieuchronnej stronniczości stanowi cenne źródło, którego fragmenty zostały potem potwierdzone przez inne świadectwa.

W czasie gdy tennō dyktował swe refleksje, Nanbara Shigeru, powszechnie szanowany rektor Uniwersytetu Tokijskiego, stwierdził publicznie, że „było niemożliwe, aby [...] cesarz zapobiegł wojnie”. Wszelako, dodawał, „sądzę, iż cesarz czuje się wobec swych cesarskich przodków najgłębiej odpowiedzialny moralnie oraz duchowo za wojnę prowadzoną w jego imieniu" ${ }^{35}$. Dlatego, przewidywał, monarcha zapewne abdykuje, bo tylko tak może się wyłonić nowa Japonia.

Domysły Nanbary były tylko częściowo trafne. W przerwach między dyktowaniem Monologu, 6 kwietnia 1946 roku, cesarz oznajmił wiceszambelanowi Kinoshicie Michio, że abdykacja osobiście mogłaby mu posłużyć, uwalniając „z bardzo trudnego położenia". Jednakże, zauważał, żaden z jego braci nie posiada kwalifikacji na regenta. Książę Chichibu był tak poważnie chory na gruźlicę, że rzadko opuszczał swą rezydencję. Takamatsu był skompromitowany z powodu swego (ongiś) jawnie powojennego stanowiska, zaś urodzony w 1915 roku książę Mikasa - „zbyt młody i niedoświadczony"36.

Wielki proces zaczął się 3 maja 1946 roku. Japończycy wciąż nie wiedzieli, że władca przed nim nie stanie. Już bowiem 29 listopada waszyngtońskie Kolegium Szefów Sztabów nakazało MacArthurowi zbadać, czy istnieją wystarczające dowody, by postawić cesarza przed IMFTE. Waszyngton wyraźnie dopuszczał takie rozwiązanie, do którego skłaniali się też niektórzy członkowie otoczenia generała ${ }^{37}$.

33 Cyt. za: N. Kawamura, op. cit., s. 187.

34 W.J. Davies (Dominion Office) do władz dominiów, 31 XII 1945, TNA, FO 371/46430/ F9703/4/23/No14.

35 Cyt. za: G. Okubo, op. cit., s. 17.

36 N. Kawamura, op. cit., s. 187.

37 R.E. Ward, Presurrender Planning: Treatment of the Emperor and Constitutional Changes [w:] Democratizing Japan. The Allied Occupation, eds. R.E. Ward, Y. Sakamoto, Honolulu 1987, s. 15; K. Takeda, The Dual Image of Japanese Emperor, London 1988, s. 131-133. 
Odpowiedź „,Zwycięzcy Pacyfiku” nadeszła 25 stycznia 1946 roku. „Żadne wyraźne i namacalne dowody - pisał MacArthur - nie świadczą, by cesarz kształtował polityczne decyzje, za które odpowiadali jego ministrowie. [...] Postawienie go przed sądem bez wątpienia spowoduje w narodzie japońskim olbrzymie wstrząsy, których skutków nie da się przecenić. [...] Zainicjowana zostanie zemsta, której cykl może nie zostać zakończony przez wieki, jeśli kiedykolwiek". Naturalnie, opór japoński nie miałby wojskowo żadnych szans, wszelako pacyfikacja ,wymagałaby minimum milionowej armii, utrzymywanej przez bliżej nieokreśloną liczbę lat”"38.

Na poglądy MacArthura dodatkowe światło rzucają refleksje, na jakie pozwolił on sobie podczas wspomnianego już spotkania z Sansomem (które miało miejsce dokładnie w dniu wysłania kluczowej depeszy do Waszyngtonu). Wedle Anglika generał

z wieloma odwołaniami do historii powszechnej rozwinął tezę, iż naturalna ewolucja sytemu politycznego w Japonii będzie podobna do krajów Europy, które przeszły z feudalizmu do monarchii absolutnej, [a następnie] stopniowo przekształcały się dzięki oddolnemu naciskowi w monarchie konstytucyjne, których najwyższą formą jest Wspólnota Brytyjska. Alternatywą, jeśli sfuszerujemy sprawę, będzie autorytarne społeczeństwo wstrętne dla Anglosasów.

Sądzi, że postawienie przed sądem cesarza jako zbrodniarza wojennego byłoby nieszczęściem. Osobiście i skrupulatnie analizując problem, odbył wiele rozmów z cesarzem [naprawdę tylko jedną; kolejna nastąpiła dopiero 31 maja 1946 - J.P.] (o którego osobistych zaletach mówił z wielkim szacunkiem) i od niego oraz z innych źródeł otrzymał dowody, iż obecny cesarz był od początku do końca marionetkąą.

Dodać mogę - konkludował Sansom - że z uwagi tak na mą dotychczasową wiedzę, jak i sporo poufnych informacji zgromadzonych tutaj podczas ostatnich trzech tygodni, pewien jestem, że osąd Najwyższego Wodza jest słuszny ${ }^{40}$.

W swej wierze w niewinność cesarza Shōwa MacArthur był niewątpliwie szczery. Opinia generała wynikała jednak także z refleksji nad dotychczasowym przebiegiem okupacji. Monarcha okazał się, bez najmniejszej przesady, kluczowym czynnikiem umożliwiającym wprowadzenie postulowanych przez aliantów reform. „Nie waham się powiedzieć - stwierdził w swych wspomnieniach minister spraw zagranicznych, a potem premier Yoshida Shigeru - że to stosunek przyjęty przez generała MacArthura wobec tronu bardziej niż cokolwiek innego uczynił okupację historycznym sukcesem" ${ }^{\prime 4}$.

Sam fakt, że to nimb cesarskiego majestatu umożliwił sprawne rozbrojenie olbrzymiej i do niedawna fanatycznie walczącej armii japońskiej, można w tym miejscu

38 Depesza MacArthura z 25 I 1946, FRUS 1946, vol. VIII, s. 395-397.

39 Notatka Sansoma, zamieszczona w: MacDermott do FO, 31 I 1946, TNA, FO 371/54082/ F1826/2/23.

40 Ibidem.

41 S. Yoshida, The Yoshida Memoirs, Cambridge, Mass. 1962, s. 50-51. 
pominąć, choć zrobił on na zwycięzcach olbrzymie wrażenie. 29 listopada 1945 roku pisał do Foreign Office MacDermott ${ }^{42}$ :

Aliancka decyzja, by utrzymać cesarza w charakterze narzędzia sprzymierzonych rządów okazała się w pełni usprawiedliwiona. Mamy obecnie obfite dowody, że wszyscy mieszkańcy Japonii mniemali, iż reskrypt 15 sierpnia 1945 r. wezwie do walki do ostatniej kropli krwi i że posłuchałby go każdy japoński mężczyzna, kobieta i dziecko. Ich posłuszeństwo wobec rozkazu zawarcia pokoju okazało się równie całkowite i niekwestionowane. Taką pokojową okupację mógł uczynić możliwą jedynie autorytet tronu ${ }^{43}$.

\section{Zszokowani zdobywcy konstatowali, iż}

Japończycy traktują nas z pełną szacunku grzecznością, udzielają wszelkich informacji oraz pomocy domyślając się z góry wszystkich naszych życzeń. [...] Cesarz, o którego pozycji debatowaliśmy tak wiele w ciągu ostatnich trzech lat, stanął na pierwszej linii 'Shin-Nippon' [Nowej Japonii - J.P.], jako orędownik demokracji, którego osobista interwencja zakończyła wojnę; dowodami są jego spotkanie z MacArthurem oraz wywiady prasowe ${ }^{44}$.

W istocie dowodów było więcej. Aliantów poruszył ogromnie wydany 1 stycznia 1946 roku reskrypt cesarski (tzw. ningen-sengen), demitologizujący monarchię i stwarzający w ten sposób grunt dla nowej, liberalnej konstytucji. Kluczowe słowa owego dokumentu, napisanego po raz pierwszy w języku bardziej potocznym (poprzednie używały archaicznych, trudno zrozumiałych sformułowań), brzmiały: „Opieramy się na ludzie, a związki miedzy nami a ludem nie zależą od legend i mitów. Nie powinny polegać na fałszywej koncepcji, iż cesarz jest boski, a Japończycy stoją wyżej od innych ras i przeznaczeni są do rządzenia światem"45.

Wszystko wskazuje - choć dowody mają charakter poszlakowy - że inicjatywa reskryptu wyszła od dworu. Głównym pomysłodawcą miał być dyrektor słynnej Szkoły Parów (Gakushüin), admirał Yamanashi Katsunoshin, przed wojną szef skłonnej do kompromisu z Londynem i Waszyngtonem tzw. traktatowej frakcji marynarki, którą to postawę polityczną przepłacił w 1932 roku przedwczesnym odesłaniem na emeryturę. Anglofil i zwolennik ewolucji monarchii w stronę rozwiązań brytyjskich, ,jeden z najwspanialszych i najbardziej sympatycznych ludzi [...] [posiadający] wszystkie cechy idealnego samuraja: odwagę, poczucie obowiązku, lojalność, wiarygodność, umiłowanie piękna, a w obliczu ubóstwa ascetyczny wdzięk życia, życzliwość, poczucie godności”46, cieszył się ogromnym szacunkiem cesarza;

42 Przy Mac Arthurze jako Naczelnym Wodzu Mocarstw Sprzymierzonych (Supreme Commander of Allied Powers, SCAP) przedstawicielem Wspólnoty Brytyjskiej, jako szef misji wojskowej, był Australijczyk, generał porucznik sir Charles Gardiner, w którego sztabie jako jedyny (początkowo) dyplomata znajdował się MacDermott. Pierwszą łącznikową misję polityczną (tzw. UKLIM, przy braku stosunków dyplomatycznych odpowiednik ambasady) objął dopiero w lipcu 1946 sir Alvary Gascoigne.

43 MacDermott do Bevina, 14 XII 1945 (jest to data wysłania depeszy, ale zamieszczony w niej długi dokument nosi datę 29 XI), TNA, FO 371/54088/F3981/2/23.

44 MacDermott do Bevina, 26 IX 1945, TNA WO 203/5645.

45 Tekst Reskryptu (w języku japońskim i angielskim): http://www.chukai.ne.jp/ masago/ningen. html [dostęp: 20.05.2017].

46 E.G. Vining, Quiet Pilgrimage, Philadelphia 1970, s. 23. Autorka znała osobiście świetnie mówiącego po angielsku admirała, gdyż to właśnie on (przynajmniej oficjalnie) zainicjował jej zatrudnienie jako guwernerki u boku japońskiego następcy tronu. 
zapytany w 1946 roku o najbardziej zaufaną osobistość, Hirohito odparł bez wahania: „Yamanashi Katsunoshin”" ${ }^{47}$. Współautorem tekstu miał być zatrudniony na kierowanym przez admirała Gakushüin brytyjski wykładowca Reginald Horace Blyth, służący także jako nieformalny łącznik z aliantami ${ }^{48}$. Jest jednak pewne, że Hirohito który jako biolog z zamiłowania uważał mity o niebiańskich początkach dynastii jedynie za legendę - nie tylko w pełni aprobował, ale może i inspirował reskrypt. Jego osobistym wkładem miało być odwołanie się w dokumencie do „Przysięgi cesarskiej w pięciu artykułach" (Gokajō no goseimon), pierwszego aktu prawnego nowoczesnej Japonii, proklamowanego 6 kwietnia 1868 roku przez cesarza Meiji ${ }^{49}$. Owszem, celem deklaracji z 1 stycznia 1946 miało być osłabienie niechęci wobec cesarza jako domniemanego zbrodniarza wojennego, lecz przesłanką ważniejszą było zaszczepienie przekonania, iż wprowadzane rewolucyjne zmiany w istocie mają korzenie w reformach jego dziadka, odbieranych w Japonii i za granicą jako czas postępu i sukcesu. Szukanie starych korzeni dla nowych, szokujących reform, przerzucanie mostu miedzy przeszłością a teraźniejszością było dla Hirohito o wiele ważniejsze niż rezygnacja z „boskości”, w którą osobiście nie wierzył.

Jest znamienne, że to, co w reskrypcie poruszało najwięcej cudzoziemców, a mianowicie cesarska rezygnacja ze statusu bóstwa, odbierana z aprobatą jako swoista „laicyzacja” monarchii, na samych Japończykach wywarła niewielkie wrażenie. Nie postrzegali oni władcy jako boga w zachodnim, ukształtowanym przez chrześcijaństwo sensie tego słowa; co ważniejsze, bóstwem (kami) nie określała władcy ani konstytucja Meiji, ani żaden z oficjalnych dokumentów ${ }^{50}$. Istotne były skutki polityczne, sprawiające, iż „niezmiernie uradowany” MacArthur już w dniu wydania reskryptu oznajmił, że cesarz „obejmuje wiodącą rolę w demokratyzacji swojego ludu. Rzetelnie określa swe stanowisko wobec przyszłości jako linię liberalną"51. W rzeczy samej, reskrypt „pozbawił energii wysiłki konserwatystów, by mobilizować opinię publiczną przeciw reformie konstytucji" ${ }^{52}$, przygotowywanej nie tyle przez Japończyków, ile przez Kwaterę Główną generała MacArthura.

47 H. Fukuda, The Peaceful Overture: admiral Yamanashi Katsunoshin [w:] Britain and Japan, 1859-1991. Themes and Personalities, eds. H. Cortazzi, G. Daniels, London-New York 1991, s. 213.

48 S. Hirakawa, R.H. Blyth and Hirohito's Denial of the Divine Character of the Tennō, „British Association for Japanese Studies. Proceedings" 1985, s. 1-33.

49 „Przysięga cesarska w pięciu artykułach” zapowiadała zwołanie „zgromadzeń” (kaigi), wzywała wszystkich, niezależnie od pozycji społecznej, do działań na rzecz kraju, zapowiadała reformy oraz „przyswajanie światowej wiedzy”. Por. E. Pałasz-Rutkowska, Cesarz Meiji (1852-1912). Wizerunek władcy w zmodernizowanej Japonii, Warszawa 2012, s. 103-105. Hirohito, przekazując premierowi Shideharze projekt ningen-sengen, poprosił, by rozszerzono go właśnie o odwołanie do „Przysięgi cesarskiej".

50 B.-A. Shillony, Divinity and Gender: The Riddle of Japanese Emperors [w:] idem, The Collected Writings of Ben-Ami Shillony, Tokyo 2000, s. 27-28. Konstytucja Meiji powiadała tylko, że dynastia ma boskie pochodzenie i jest wieczna (bansei ikkei).

51 Cyt. za: Political Reorientation of Japan, vol. II, Westport, Conn. 1970, s. 471.

52 M. Schaller, The American Occupation of Japan. The Origins of Cold War in Asia, New York 1985, s. 42. 
Logicznym następstwem popularyzowania nowego „cesarza ludowego” (shiminteki tennō) stał się rozpoczęty w czerwcu 1946 roku i kontynuowany aż do roku 1951 cykl wielkich podróży władcy. Wedle szefa misji brytyjskiej, sir Alvary’ego Gascoigne'a, pomysłodawcą tego kroku był MacArthur ${ }^{53}$. Dla Japończyków chodziło jednak (znów) o oczywiste nawiązanie do czasów cesarza Meiji, który w latach 1877-1899 odbył osiem wielkich objazdów swego państwa, inspekcjonując i nadzorując stan wprowadzanych reform ${ }^{54}$. Rezultaty przedsięwzięcia przeszły wszelkie oczekiwania. Ku zdumieniu zdystansowanych, jeśli nie wręcz niechętnych zagranicznych dziennikarzy zwykli ludzie ,zamiast zwrócić się przeciw niemu [tennō] z gorzkim rozczarowaniem, zdawali się troszczyć o niego i chronić przed światem"55. Aliancka Kwatera Główna odnotowała natomiast, iż „fakt, że cesarz wielokroć wspominał Najwyższego Dowódcę Sił Alianckich [...], powinien mieć korzystny wpływ na reedukację Japończyków"56.

Rozpoczęcie cesarskiego tournée zbiegło się w czasie z przedstawieniem przez władce parlamentowi projektu nowej konstytucji (20 czerwca 1946). Dokument, której autorstwo w ścisłym tego słowa znaczeniu jest nadal niejasne, był dziełem współpracowników MacArthura. Pomysły współpracujących z premierem Shideharą konstytucjonalistów japońskich, proponujących w sumie niewielkie korekty dotychczasowej konstytucji Meiji, zostały niemal całkowicie zignorowane. Ponieważ jednak nowa ustawa zasadnicza była formalnie modyfikacją starej, musiała zostać jeśli nie chciano zrywać ciągłości prawnej państwa - zaproponowana przez cesarza. Jej postanowienia były dla wielu Japończyków szokujące; porażał nie tyle sławny dziś art. 9, potępiający wojnę i wyrzekający się utrzymywania sił zbrojnych - gdyż takowe od kapitulacji nie istniały - ile zredukowanie cesarza do roli „symbolu państwa i jedności narodu”. Ale „kiedy premier Shidehara i minister spraw zagranicznych Yoshida zwrócili się o opinię do cesarza, usłyszeli oniemiali, że cesarz popiera wszystkie propozycje MacArthura, nawet te, które pozbawiały tron wszelkiej władzy politycznej” ${ }^{57}$. Po wejściu ustawy zasadniczej w życie tennō oznajmił wręcz manifestacyjnie w dniu 3 maja 1947 roku: „cieszę się, iż podwaliny pod budowę nowej Japonii zostały położone zgodnie z wolą narodu japońskiego" 58 .

Instytucja monarchii okazywała się więc kluczowa dla powodzenia okupacji. Jednakże sytuacja, gdy MacArthur uczynił siebie jedynym kanałem dostępu do cesarza, krępowała zarówno tennō, jak i Brytyjczyków (jedynych poza Amerykanami aliantów mających wpływ na proces przebudowy Japonii). Już w listopadzie 1945 roku Yoshida poufnie informował, że cesarska rozmowa z brytyjskim dziennikarzem jest niemożliwa, bo nie zgodzą się na nią Amerykanie ${ }^{59}$. Przez tych ostatnich rozumieć

53 Gascoigne do Bevina, 1 I 1947, TNA, FO 410/99/F17776/1776/23.

54 Por. E. Pałasz-Rutkowska, op. cit., s. 225-252.

55 R. Brines, MacArthur's Japan, New York-Philadelphia 1948, s. 84.

56 Gascoigne do Bevina, 20 XII 1947, FO 371/69/837/F53/53/23.

57 Ch.A. Willoughby, J. Chamberlain, MacArthur 1941-1945. Victory in the Pacific, Melbourne 1956.

58 Cyt. za: S.S. Large, op. cit., s. 151; szerzej: K. Starecka, Geneza..., s. 67-80.

59 MacDermott do FO, 17 XI 1945, TNA, FO 371/46431/ F11227/4/23. 
należało personalnie „zwycięzcę Pacyfiku”, nie dyplomatów USA, skoro jeszcze w lipcu 1951 roku Gascoigne skarżył się, iż „żaden z szefów misji nie widział cesarza od początku okupacji. Ta sztywna reguła stosowała się tak do mego amerykańskiego kolegi, jak i do każdego z nas" ${ }^{60}$. Wyjątki od owej reguły zawdzięczano osobistej łaskawości potężnego namiestnika. 24 stycznia 1947 roku cesarza i jego małżonkę Nagako odwiedził sir Miles Lampson. Ów wyborny dyplomata był znawcą Japonii i (zwłaszcza) Chin, gdzie spędził znaczną część życia; stosunkowo niedawno (w 1943 roku) witał w Kairze, jako Wysoki Komisarz dla Egiptu i Sudanu, przybyłego konferować z Churchillem i Rooseveltem swego starego znajomego Czang Kaj-szeka ${ }^{61}$. $Z$ cesarzem miał o czym rozmawiać: wiosną 1921 roku towarzyszył młodemu księciu Hirohito podczas objazdu Szkocji. Propozycja spotkania wyszła dość nieoczekiwanie ze strony MacArthura, żywiącego dla Lampsona (którego poznał w lipcu 1946 podczas ceremonii nadania niepodległości Filipinom) sporą osobistą sympatię. Sir Miles stał się w ten sposób pierwszym brytyjskim (jeśli nie jakimkolwiek alianckim) dyplomatą, który widział Hirohito po grudniu 1941 roku.

Podczas dwugodzinnego spotkania „tak cesarz, jak i cesarzowa byli niezwykle przyjaźni i nie mogli być mniej formalni”. Hirohito oznajmił, że oglądał „w kolorze” ślub następczyni tronu księżniczki Elżbiety, i „usilnie prosił, aby jego wyrazy szacunku mogły być przekazane Ich Królewskim Mościom”. Następnie „ze smutkiem mówił o swym usilnym pragnieniu ujrzenia podobnie szczęśliwego stanu rzeczy tutaj, w Japonii, oceniając go jako wzór, do którego pragnie dążyć. Oświadczył, że jego ambicją jest usilna i stała praca zmierzająca w tym kierunku, aby ukształtować jego własną pozycję jak najbliżej wzoru brytyjskiego, który tak bardzo podziwia”. Zapytany o możliwość szybkiego zbudowania demokracji, „z wymuszonym uśmiechem” wyjaśnił, iż ,jest to bardzo trudne”, wszelako ,jest zdeterminowany wytrwać - przy czym raz jeszcze nawiązał do Korony Brytyjskiej oraz systemu brytyjskiego jako oczywistego modelu, na którym zamierza się wzorować”. Następnie oznajmil, iż „ubolewa nad ostatnią wojną i stwierdził kategorycznie, że był zawsze przeciw niej". Przeprosił też za „straszne cierpienia i zniszczenia” spowodowane przez „Japończyków”. Atmosfera stała się tak ciepła, iż Lampson, umówiony tegoż dnia na spotkanie w Jokohamie $\mathrm{z}$ dowódcą 8. Armii USA, generałem Robertem Eichelbergerem, był w niemałym kłopocie, chcąc jakoś zasygnalizować - nie gwałcąc dworskiej etykiety - że jego czas dobiega końca.

Choć [cesarz] nie powiedział tego wprost - podsumowywał rozmowę Gascoigne - to dał w sposób oczywisty do zrozumienia (i pewny jestem, iż celowo), że żywi i zawsze żywił bardzo mocne uczucia probrytyjskie: wydawał się wzruszająco gotowy ukazać swe zdecydowane i głębokie ubolewanie za niegodziwe czyny Japonii podczas ostatniej wojny. Z pewnością ani on, ani cesarzowa (która zaprezentowała się, jeśli mogę użyć tego określenia, nie uchybiając należnemu szacunkowi, niczym stara kumpelka z przylepionym uśmiechem, zaśmiewająca się z najmniej skomplikowanych dowcipów) nie mogliby zapewnić nam cieplejszego czy bardziej

60 United Kingdom Liaison Mission do FO, 17 VII 1951, TNA, FO 371/92712/22/5/51.

${ }_{61}$ O Lampsonie i jego politycznej roli w Chinach piszę obszernie w pracach: J. Polit, Lew i smok. Wielka Brytania a kryzys chiński 1925-1928, Kraków 2006; Pod wiatr. Czang Kaj-szek 1887-1975, Kraków 2008. 
nieformalnego oraz (jeśli raz jeszcze mogę użyć trywialnego sformułowania) „poufałego” przyjęcia $^{62}$.

Lecz przełamanie monopolu na dostęp do cesarza na dłuższą metę nie okazało się możliwe. Fiaskiem zakończyła się próba przydania następcy tronu Akihito brytyjskiego preceptora; MacArthur ,z powodów, które mogę jedynie z największym żalem przypisać zazdrości o brytyjskie wpływy tutaj” ${ }^{63}$ sprzeciwił się mu, i to „,mimo faktu, że, jak nam wiadomo z pewnych źródeł, nominacja byłaby witana więcej niż radośnie przez samego cesarza, jego dwór i pana Yoshidę, premiera Japonii" ${ }^{64}$. Niewiele pomogły dyskretne westchnienia na sztab ,zwycięzcy Pacyfiku” (nie jego samego), których nie szczędził 10 marca 1948 roku współpracownikowi Gascoigne’a, H. Vere Redmanowi, książę Takamatsu ${ }^{65}$. Ani on, ani książę Chichibu, „niezwykle przyjazny wobec Anglii, którego wysiłki w celu zdemokratyzowania dworu, gdyby się powiodły, mogłyby się okazać bardzo korzystne"66, nie mogli zastąpić najstarszego z braci. „Respekt odczuwany przez Japończyków dla ich monarchy, nigdy niezachwiany po kapitulacji, może jeszcze wzrósł podczas tego roku - stwierdzał Gascoigne w ostatnich dniach 1947 - a kompetentni obserwatorzy zapewnili mnie, iż na Hirohito spoglądano z większą miłością i szacunkiem niż przed wojną" ${ }^{67}$. W tej sytuacji ewentualna abdykacja cesarza, której od czasu do czasu żądały jeszcze rozmaite kręgi w Waszyngtonie, Londynie i Canberze, groziłaby ruiną całego procesu okupacyjnej przebudowy Japonii. Sens owej groźby streścił bodaj najcelniej zatrudniony w Sekcji Dalekowschodniej brytyjskiego Foreign Office Arthur de la Mare, zalecając natychmiastowe wygaszenie zgłoszonej w Izbie Gmin interpelacji o szybkie złożenie z tronu cesarza Shōwa:

Cesarz jest największym atutem, jaki posiadamy, kontrolując Japonię. To nie bomba atomowa spowodowała japońską kapitulację; polecił im to uczynić cesarski reskrypt. Bez niego czekałaby nas kosztowna inwazja Japonii i beznadziejne zadanie pacyfikacji już zajętego kraju. O ile wiem, po kapitulacji ani jeden żołnierz aliancki nie stracił życia w wyniku wrogiego działania ze strony Japończyków. Wynika to wyłącznie z faktu, iż Japończycy, nawet fanatyczni, wykonują rozkazy cesarskie.

Gdybyśmy oskarżyli cesarza, stanęlibyśmy natychmiast w obliczu siedemdziesięciu milionów wrogich, a nie skłonnych do współpracy Japończyków. Zadanie kontrolowania Japonii stałoby się nie tylko nieskończenie trudniejsze - stałoby się niemożliwe. Są wszelkie powody do wiary, iż pod kierownictwem cesarza Japończycy wkroczyli na nową ścieżkę pokoju i demokracji. Bez cesarza nie ma szans na cokolwiek prócz chaosu i ostatecznego odrodzenia ideologii agresji.

Niezależnie od tego, iż oskarżenie cesarza jest politycznie niepożądane, wydaje się niezmiernie wątpliwe, czy jakikolwiek rzetelny sąd mógłby uznać go za zbrodniarza wojennego. Wszelako

${ }^{62}$ Interview between Lord Killearn and the Emperor Hirohito, 24 I 1947 [w:] Gascoigne do FO, 6 II 1947, TNA, FO 371/69912/F2024/2023/23.

${ }_{63}$ Gascoigne do FO, 22 V 1950, TNA, FO 371/83815/10111/34.

${ }_{64}$ Trends of Event in Japan from July 1946 to February 1951, 12 II 1951, TNA, FO 371/92521/ FJ1091/5.

65 H. Vere Redman, Memorandum, 10 III 1948, TNA, FO 371/69820/ F4930/44/23.

${ }_{66}$ Gascoigne do Deninga, 15 III 1948, TNA, FO 371/69820/ F4930/44/23.

67 Gascoigne do Bevina, 1 I 1948, TNA, FO 371/69914/F2199/2199/23. 
jego oskarżenie, nawet gdyby ostatecznie skończyło się uniewinnieniem, wywarłoby na Japończykach wrażenie niemal tak złe jak egzekucja; odrzucilibyśmy tylko nasz atut dla wątpliwej przyjemności postawienia go przed sądem. Wszelako nie jest prawdopodobne, by cesarz pozwolił się aresztować. Najprawdopodobniej popełniłby samobójstwo, a my stanęlibyśmy w obliczu męczeńskiej legendy, której nie wykorzenilibyśmy przez stulecia ${ }^{68}$.

Choć w Departamencie Stanu USA ciągle istniały sfery niechętne cesarzowi, do utrzymania na tronie cesarza Shōwa zdecydowanie dążyli zarówno generał MacArthur, jak i Brytyjczycy. Wpływ tych ostatnich na „zwycięzcę Pacyfiku”, choć na pewno ograniczony, nie powinien być niedoceniany. „Przed opuszczeniem Londynu ostrzegany byłem - przyznawał sir Alvary - że generał MacArthur może być człowiekiem trudnym we współpracy, ponieważ ma skłonności anglofobiczne. Jedyną sprawiedliwą rzeczą będzie przyznanie, że po moim przybyciu tutaj powitany zostałem przez generała z największą przyjaźnią i uprzejmością, jako członek jego «dworu»" ${ }^{\circ}$. Co się zaś tyczy linii politycznej MacArthura, „która nie uniknęła ostrej krytyki ze strony wielu organów prasy alianckiej, za jej jakoby przesadną pobłażliwość wobec barbarzyńskiego i nieludzkiego wroga, to jestem mocno przekonany, że nie mogłaby być ona lepiej prowadzona i wykonywana"70.

W sytuacji politycznej, jaka rozwinęła się w latach 1947-1948, możliwość abdykacji cesarza mogła być środkiem nacisku nie władz okupacyjnych na Hirohito, lecz właśnie cesarza na władze okupacyjne. Tymczasem kwestia abdykacji tennō stanęła ponownie na porządku dziennym pod koniec 1948 roku w związku z dobieganiem końca prac IMFTE. Od początku oczywiste było, że wobec ogromu ujawnionych zbrodni proces zaowocuje licznymi wyrokami śmierci. Nie ma tutaj miejsca na jego szerszą analizę ${ }^{71}$. Istotne, że zeznania głównych oskarżonych zdecydowanie rozgrzeszały cesarza. Zasadniczą rolę miało tu świadectwo wspomnianego już premiera Tōjō Hidekiego. Niedawny „wielki shōgun wojny” zapewnił: „o wojnie zadecydował mój rząd. [...] Mogło się to stać wbrew jego [cesarza] woli, niemniej pozostaje faktem, że za moją radą i za radą Naczelnego Dowództwa cesarz skłonił się, aczkolwiek niechętnie, ku wojnie". Także w innych wypowiedziach Tōjō podkreślał, że „cesarz nigdy nie rozkazywał [...] [a] rady rządu i Naczelnego Dowództwa nigdy nie były odrzucane"72. Wypowiedzi pozostałych oskarżonych wspierały owo stanowisko. Abstrahując od faktu, czy było ono całkowicie zgodne z prawdą historyczną ${ }^{73}$, obiektywnie działało jak najbardziej na korzyść sprawy monarchii. Główny oskarży-

68 Possibility of indictment of the Emperor of Japan as a War Criminal, $6^{\text {th }}$ December 1945, TNA, FO 371/46431/F11883/4/23.

69 Gascoigne do FO, 12 II 1951, TNA, FO 371/92521//FJ1019/5.

70 Gascoigne do Bevina, 1 I 1947, TNA, FO 410/60/F1776/1776/23.

${ }_{71}$ Rzetelnie informuje na ten temat Katarzyna Starecka, Kontrowersje dotyczace prawa ex post facto w świetle Międzynarodowego Trybunatu Wojskowego dla Dalekiego Wschodu, „Japonica” 1995, nr 4, s. 66-74.

72 Cyt. za: K. Takeda, op. cit., s. 142-143.

73 Ostatnio znacznej osobistej roli cesarza w japońskich decyzjach politycznych i wojskowych usiłował dowieść Herbert P. Bix (Hirohito and the Making of Modern Japan, New York 2000). Jego głośna praca, przychylnie przyjęta przez media, spotkała się jednak z nader krytycznymi recenzjami specjalistów. 
ciel Joseph B. Keenan przypuszczał post factum, że cesarz, gdyby musiał zeznawać, zapewne „wziąłby odpowiedzialność osobistą za wszystkie działania rządu japońskiego, negując wszelkie przeciwne dowody" "74, co wydaje się nader prawdopodobne.

„Dynamiczne wypowiedzi Tōjō” wywołały w społeczeństwie japońskim pewną sympatię dla byłego premiera, nad czym ubolewali alianci. Przed wszystkim posłużyły jednak sprawie cesarza. Mieszkańcy Wysp mogli przeczytać w gazetach zapewnienia, że gdy Tōjō przedstawił tennō nieuchronność wojny,

mógł wyczytać z fizjonomii Jego Cesarskiej Mości, iż przeżywa on głęboką rozpacz wynikłą z jego umiłowania pokoju. Gdy Jego Cesarska Mość usłyszał, co musimy mu przedłożyć, przez pewien czas siedział posępny i pogrążony w myślach. [...] A nawet gdy rząd postanowił wojnę, cesarz, zapewnia Tōjō, poczynił jeszcze jeden ostatni wysiłek, by jej zapobiec ${ }^{75}$.

Pełna wręcz samobójczej lojalności postawa głównych oskarżonych pogłębiła wszakże depresję cesarza, głęboko przeżywającego fakt, że pozostaje na tronie, w czasie gdy jego podwładni mają maszerować na szafot. Zauważono, iż „w miarę jak proces zbrodniarzy wojennych zbliżał się ku końcowi, Jego Cesarska Mość stał się osobiście niezmiernie przygnębiony i niechętnie pojawiał się publicznie" ${ }^{\text {" }}$, zaniechując na pewien czas podróży. Dotychczasowe założenie, że złożenie władzy powinno być poprzedzone zawarciem traktatu pokojowego, a przynajmniej wejściem w życie kluczowych reform, zostało poważnie zachwiane. Wyrazem rozterek była wypowiedź zanotowana 8 maja 1948 roku: „Sądzę, że gdybym był w stanie abdykować, osobiście byłbym szczęśliwy. Jednakże bardzo pragnąłbym ujrzeć jak działa oraz zaczyna działać japońska demokracja" "77.

Fraza „gdybym był w stanie abdykować” nie była retorycznym zwrotem. Nowa konstytucja Japonii, podobnie zresztą jak stara, nic nie mówiła o możliwości abdykacji. Czyżby jedynym godnym wyjściem stawało się samobójstwo?

Pogłoski o abdykacji docierające do władz alianckich poprzez przecieki zamierzone, być może, przez cesarskie otoczenie wywołały ogromne zaniepokojenie. Eskalacja zimnej wojny, której głównym objawem w Azji była postępująca katastrofa Chin Czang Kaj-szeka, mających być wszak w planach Waszyngtonu filarem stabilizacji i wpływów USA w tej części świata, wykluczała możliwość destabilizacji Japonii. William Sebald, wspomniany już szef Sekcji Dyplomatycznej Naczelnego Dowództwa Mocarstw Alianckich i jeden z najbliższych współpracowników MacArthura, ujął potem problem następująco: „Abdykacja bez wątpienia pozostawiłaby samą instytucję tronu nietkniętą, przy następcy tronu Akihito, wówczas piętnastoletnim... Ale cały system władzy i kontroli, symbolizowany przez stosunki Hirohito z MacArthurem, mógł zostać nagle zniszczony, tworząc chaos lub, co najmniej, wszelką okazję do chaosu"78.

74 Cyt. za: K. Takeda, op. cit., s. 141.

75 Emperor Hirohito. He Holds Japan Together, „Nippon Times”, 8 I 1948.

76 Gascoigne do Bevina, Annual review for 1949, 1 I 1949, TNA, FO 371/76176/F1336/1011/23.

77 I. Hata, Hirohito. The Shōwa Emperor..., s. 201; por. też S.S. Large, op. cit., s. 141, i K. Starecka, Geneza ..., s. 66-67.

78 W.J. Sebald, With MacArthur in Japan. A Personal History of Occupation, London 1965, s. 165. 
W czerwcu 1948 roku dwór japoński poufnie poprosił misję brytyjską o informacje na temat okoliczności abdykacji księcia Windsoru, przez niespełna 11 miesięcy 1936 roku panującego (choć nigdy niekoronowanego) jako Edward VIII. Zbyty uprzejmymi ogólnikami, po pewnym czasie „,poruszył sprawę jeszcze raz, prosząc, czy mógłby otrzymać tekst uchwalonego wówczas dokumentu". Wystraszony Gascoigne odmówił, wyjaśniając, iż „taka prośba musiałaby zostać złożona oficjalnie, poprzez Najwyższego Dowódcę Mocarstw Sprzymierzonych [MacArthura - J.P.]”. „Sądzę informował Londyn - że byłoby dla nas kwestią niezwykle niebezpieczną [podkreśl. w oryginale - J.P.] dać się uwikłać w owe pogłoski abdykacyjne”. Zwierzchnicy zgodzili się całkowicie, konkludując, iż nie mogą ,przekazywać kopii uchwały [abdykacyjnej] poza plecami SCAP, o którym wiemy, że jest zdecydowanie przeciwny abdykacji”79. Czy jednak japońskie posunięcie podejmowane było na serio, czy też miało jedynie wysondować, jeśli nie wystraszyć, drugą stronę?

Foreign Office, zaniepokojone samą możliwością abdykacji jako takiej, zaskoczone było - $\mathrm{i}$ to najwidoczniej niemile - że jako kandydat na regenta wymieniany jest książę Takamatsu (przypomnijmy, trzeci w kolejności syn zmarłego cesarza Taishō), a nie jego starszy brat książę Chichibu. Zapytywano, czy ten ostatni jako członek Rady Regencyjnej nie ma automatycznego pierwszeństwa i czy został „definitywnie skreślony" ${ }^{80}$. Sir Alvary Gascoigne wyjaśnił wszakże, iż wzmianka o Radzie Regencyjnej jest nieporozumieniem. Artykuły 16 i 17 promulgowanego 19 stycznia 1947 roku nowego Aktu o Domu Cesarskim mówiły mianowicie wyraźnie, że w wypadku niezdolności cesarza do pełnienia jego funkcji, regenta - przy czym roli tej nie może pełnić ciało zbiorowe - mianuje Rada Domu Cesarskiego. Ta ostatnia instytucja liczy 10 członków, wśród których - oprócz premiera, reprezentantów obu izb parlamentu oraz dworu - znajduje się dwóch członków rodziny panującej. Tymi ostatnimi są aktualnie, wyjaśniał Gascoigne, brat cesarski książę Takamatsu oraz Setsuko, księżna Chichibu, ale nie sam książę. Owszem, wspomniany art. 17, wyliczając uprawnionych do sprawowania regencji, mówi najpierw o następcy tronu (ale ten jest obecnie małoletni), a potem o książętach (nie księżniczkach!) krwi, „wedle kolejności urodzenia”, przez co Chichibu miałby przewagę.

Wszelako pozostaje faktem, iż jest on w tak złym stanie zdrowia, że członkowie Departamentu Rodziny Cesarskiej [błąd; powinno być Agencji Dworu Cesarskiego - J.P.] czują, że byłby on niezdolny wykonywać owe obowiązki. [...] Choć z każdego punktu widzenia byłoby najlepszym rozwiązaniem, gdyby owo stanowisko objął książę Chichibu, to, z powodów wyłuszczonych powyżej, prawdopodobieństwo tego zdaje się być niewielkie ${ }^{81}$.

W chwili wymiany omówionych powyżej depesz kryzys abdykacyjny zdążył wszakże przeminąć, choć okoliczności jego przezwyciężenia pozostają nieco tajemnicze. Rzecz rozegrała się w trójkącie cesarz-Mac Arthur-Yoshida, przy czym ten

79 Gascoigne do MacDermotta, 26 VI 1948, TNA, FO 371/69837/F9619/53/23; ostatni cytat to minute Dudleya Cheke'a z Foreign Office Far Eastern Department.

80 P.W. Scarlett (FO) do sir Alvary'ego Gascoigne, 2 II 1949, TNA, FO 371/76256/F13801941/23.

81 Gascoigne do FO, 19 II 1949, TNA, FO 371/76256/FO 371/3249/1941/23. 
ostatni, od 15 października 1948 roku ponownie premier ${ }^{82}$, pełnił tylko rolę pośrednika. „Zwycięzca Pacyfiku” rozważał podobno natychmiastowe spotkanie z tennō, uznał jednak, że nie może ono nastąpić przed wydaniem wyroku przez IMFTE (wszystko wskazuje, iż chciał uniknąć prośby o złagodzenie werdyktu). W tej sytuacji Yoshida spotkał się z MacArthurem 5 listopada o szóstej wieczorem, następnie 11 listopada o tej samej godzinie i wreszcie 12 listopada w południe. Każde spotkanie trwało nie więcej niż pół godziny. 12 listopada wspomniany już Terasaki Hidenari dostarczył alianckiemu głównodowodzącemu krótki list, sygnowany przez Wielkiego Stewarda Dworu (Kunaichō Chōkan) Tajimę Michiji. Zawierał on nieopatrzoną datą wiadomość od cesarza o treści następującej:

Jestem niezmiernie wdzięczny za uprzejmą i taktowną wiadomość, którą Wasza Ekscelencja zechciał przekazać mi tego dnia za pośrednictwem premiera Yoshidy. Moim najwyższym pragnieniem jest służenie sprawie pokoju światowego i promowanie dobrobytu oraz szczęścia mojego ludu. Obecnie bardziej niż kiedykolwiek zdeterminowany jestem pragnieniem, by wraz z moim ludem zrobić wszystko, co w mej mocy, celem przezwyciężenia wszystkich trudności i przyspieszenia narodowej odbudowy Japonii ${ }^{83}$.

Co zawierała „uprzejma i taktowna wiadomość”, nie jest jasne, choć przypuszczać można, iż nie została sformułowana na piśmie (inaczej cesarska odpowiedź nawiązywałaby do jej daty). Wątpić też można - choć czasem się tak sugeruje - czy poprzedzona została jakimś innym pismem cesarza, na przykład zawierającym prośbę o łaskę dla skazanych. Istotne jest, że o abdykacji nie było już mowy. 23 grudnia miała miejsce egzekucja siódemki osób skazanych przez Trybunał na śmierć, w tym byłych premierów Hiroty i Tōjō, o czym cesarza zawiadomił z niedużym wyprzedzeniem prokurator aliancki Joseph B. Keenan. Przypadkowo były to urodziny następcy tronu. „Cesarz spędził ten dzień w odosobnieniu, a następca tronu nie mógł pójść do pałacu, aby świętować swe piętnaste urodziny razem z rodziną" ${ }^{44}$.

Mimo dyskrecji MacArthura, doprowadzającej często historyków do rozpaczy, pewne światło na sprawę rzucają jego wynurzenia przed E. Herbertem Normanem, szefem kanadyjskiej misji w Japonii. W rozmowie z 8 stycznia 1949 roku generał określił sprawę abdykacji jako sztuczną aferę, stymulowaną jakoby przez zagranicznych dziennikarzy. Stwierdził jednak, że

Hirohito zapytał go, jaki kurs ma obrać, i wyznał, że jest gotów abdykować, gdyby takie było życzenie aliantów. Gdyby ci jednak nie dążyli do jego odejścia, pełniłby swą misję do końca. Wówczas MacArthur zapewnił Jego Cesarską Mość, że cała sprawa jest dęta (artificial one) i że nie ma żadnej konieczności abdykacji. Podczas dalszej dyskusji dotyczącej cesarza generał MacArthur zapewnił doktora Normana, iż [obecny] cesarz jest o wiele lepszym władcą, niż książę Takamatsu mógłby kiedykolwiek być ${ }^{85}$.

82 Po raz pierwszy Yoshida był premierem (po Shideharze) 22 V 1946-24 V 1947.

83 Cyt. za: R.B. Finn, Winners of Peace. MacArthur, Yoshida and Postwar Japan, Berkeley 1992, s. 189.

84 E.G. Vining, Windows for the Crown Prince. Akihito of Japan, Boston 2000, s. 172.

85 Discussion between the Supreme Commander, General MacArtur and M. Norman, head of the Canadian Mission, regarding rumours of abdication of the Emperor of Japan [w:] Gascoigne do Bevin, 13 I 1949, TNA, FO 371/76 256/F1380/1941/23. 
Deklaracja MacArthura wywołała ulgę w brytyjskich sferach rządowych i dworskich. Zawiadomiono także Buckingham Palace, poprzez sir Alana Lescellesa, sekretarza króla Jerzego VI (a potem jego córki Elżbiety). „Zobaczysz - pisał do „drogiego Alana" R.D.C. McAlpine w liście dołączonym do cytowanych powyżej dokumentówże abdykacja nie wchodzi w grę. Generał MacArthur wskazuje też, iż widzi korzyści $\mathrm{z}$ utrzymania w Japonii cesarskiego systemu" ${ }^{\prime \prime 6}$.

Po raz ostatni z możliwością abdykacji rządy amerykański i brytyjski liczyły się - ale tylko przelotnie - w lecie 1951 roku, gdy przygotowany przez oba mocarstwa anglosaskie traktat pokojowy został ostatecznie sformułowany (jak wiadomo, zawarto go 8 września tegoż roku w San Francisco). Choć pozostawała jeszcze kwestia jego ratyfikacji i ostatecznego wejścia w życie (traktatu nie podpisali ZSSR oraz jego polscy i czechosłowaccy satelici), było oczywiste, że okupacja, będąca w dziejach Japonii całą epoką i swoistą rewolucją, dobiegała końca. Postawiło to znów na porządku dziennym rozważaną od lata 1945 roku kwestię, czy misja cesarza Shōwa, polegająca na szczęśliwym przeprowadzeniu narodu przez największą w dziejach zawieruchę, mogłaby także zostać zakończona.

W poufnych rozmowach z Brytyjczykami przedstawiciel ministerstwa spraw zagranicznych Matsumoto Kaoru (wątpliwe jednak, czy z inspiracji dzierżącego tekę szefa dyplomacji premiera Yoshidy, znanego z przywiązania do cesarza) miał jakoby napomknąć, iż tennō liczy się z ustąpieniem ,z powodu swej odpowiedzialności za wojnę" i że „istnieje znaczne poparcie dla propozycji, że regentką powinna zostać żona księcia Chichibu" "'7 . Geneza owej wypowiedzi nie jest jasna. Rzekoma kandydatka na regentkę była bez wątpienia najlepiej na Downing Street notowaną osobą z rodziny cesarskiej; jako pierwsza jej przedstawicielka miała po wojnie odwiedzić Wielką Brytanię, gdzie gościła potem jeszcze wielokrotnie. Możliwe, że Matsumoto reprezentował kręgi dworu zbliżone do dawnego kanclerza tajnej pieczęci Kido. Ten ostatni, skazany przez IMFTE na dożywocie, ale mający nadzieję na ułaskawienie (więzienie opuścił w 1953 roku, przeżywając jeszcze ćwierćwiecze), miał 17 października 1951 roku, czyli już po zawarciu pokoju w San Francisco, wystosować przez swego syna Takahiko apel do wielkiego mistrza ceremonii dworu cesarskiego, Matsudairy Yasumasy. Wzywał do abdykacji, wskazując, iż jeśli tak się nie stanie, „W rezultacie rodzina cesarska będzie jedyną, która nie poniesie odpowiedzialności [za wojnę], a wówczas przetrwają niekorzystne nastroje, co, jak się obawiam, stać się może nieusuwalnym piętnem" ${ }^{\prime 8}$.

Obawy aliantów zostały wszakże szybko rozwiane. Niebawem, podczas przyjęcia w poselstwie belgijskim, gdy rozmowa zeszła na niedawną (dokonaną 16 lipca 1951) abdykację króla Leopolda III, oskarżanego o wspieranie kolaboracji podczas wojny, obecny wśród dyplomatów Matsudaira oznajmił: „nie sądzę, by coś takiego mogło się kiedykolwiek wydarzyć w Japonii”. Brytyjczycy wskazywali, że choć cesarza nadal dręczy „,kompleks winy wojennej”, to został on przekonany, iż „nie wolno mu

86 R.D.C. McAlpine do sir Alana Lescellesa, Buckingham Palace, 1 II 1949, ibidem (ta sama sygnatura).

87 Ambasada w Tokio do Charlesa Johnsona, 7 VIII 1951, TNA, FO 371/92712/FJ450/2/51.

88 Cyt. za: N. Kawamura, op. cit., s. 189. 
rozważać żadnych niefortunnych kroków w obliczu młodego wieku następcy tronu". Co się zaś tyczy Setsuko, księżnej Chichibu, to „naturalnie, nie ma wątpliwości co do przymiotów jej umysłu, charakteru i jej ogólnej popularności. Tak więc jej nominacja jako regentki, gdyby wystąpiła taka potrzeba, spotkałaby się z ciepłym przyjęciem. Wszelako według ostatniego Prawa Dworu Cesarskiego, promulgowanego w styczniu 1947 roku, nie kwalifikuje się ona na takie stanowisko, ponieważ nie pochodzi z legitymizowanej linii cesarskich potomków ${ }^{89}$. Jedyną żyjącą osobą spoza takiej linii mającą odpowiednie kwalifikacje jest [aktualna] cesarzowa”. Uspokojone Foreign Office oceniło (w notatce z 14 sierpnia 1951), że „obecnie istnieje niewielka lub zgoła żadna presja na abdykację"90.

Niepokój Brytyjczyków był tym bardziej zrozumiały, że kończący właśnie w 1951 roku 18 lat następca tronu uważany był za młodzieńca „,niewykazującego inklinacji do nawiązywania rozmów” i wręcz „pozbawionego kwalifikacji towarzyskich”. Tym razem jednak obawy okazały się płonne. 17 listopada (miesiąc po oficjalnej inwestyturze w pałacu) młody Akihito gościł w towarzystwie swej elokwentnej stryjenki księżnej Chichibu na oficjalnej kolacji w ambasadzie brytyjskiej „w sposób oczywisty zdeterminowany, by wykonać swój obowiązek, choć naturalnie świadom niedoskonałości swego angielskiego" ${ }^{\prime 1}$. Zrobił bardzo pozytywne wrażenie, a w roku następnym z powodzeniem reprezentował Japonię na koronacji Elżbiety II.

Samemu cesarzowi Shōwa bliskie były przynajmniej niektóre argumenty zawarte w proabdykacyjnym przesłaniu Kido, które obudzić w nim musiało dawne wątpliwości. Wszelako odpowiedź Matsudairy, datowana na 28 listopada, stwierdzała, że choć cesarz, Tajima i on sam, Matsudaira, skłanialiby się do abdykacji, premier Yoshida „nie jest zainteresowany” takim rozwiązaniem ${ }^{92}$. Nie wydaje się, aby było to tylko wygodne przerzucenie odpowiedzialności. Cesarz i Yoshida czuli się związani niedawnymi zapewnieniami o pozostaniu na tronie złożonymi MacArthurowi oraz, de facto, aliantom. Trwała nadal zimna wojna oraz wojna w Korei, balansująca na krawędzi III wojny światowej. Następca tronu miał się niebawem sprawdzić znakomicie w swej podróży do Wielkiej Brytanii, była to jednak przyszłość, a zastąpienie dwudziestolatkiem panującego z trzydziestoletnim (jeśli wliczyć okres regencji Hirohito sprawowanej w imieniu ojca) stażem na tronie wydawało się wielce ryzykowne.

Ostatecznie abdykacyjne spekulacje rozwiało uroczyste wystąpienie cesarza w dniu 3 maja 1952 roku, będące - wobec ratyfikacji traktatu pokojowego - świętem odzyskania suwerenności. Tennō mówił o ,głębokiej refleksji” nad błędami przeszłości, ale także o swej determinacji w dźwiganiu ciężaru panowania $\mathrm{w}$ ciągu nadchodzących lat.

89 Księżna Chichibu, urodzona w 1909 r. jako Matsudaira Setsuko, mimo arystokratycznego pochodzenia (jej dziadek od strony ojca, Matsudaira Katamori, był feudalnym panem [daimyo] Aizu, pochodzącym z młodszej linii siogunów z rodu Tokugawa) nie wywodziła się z rodziny panującej.

90 Ambasada w Tokio do Charlesa Johnsona, 7 VIII 1951, TNA, FO 371/92712/FJ450/2/51; ostatni cytat to osobista notatka (minute) R.S. Mitforda.

91 Dening do FO, 17 XII 1952, TNA, FO 371/99533/F1945/9.

92 N. Kawamura, op. cit., s. 189. 
Brak jasno wyrażonych przeprosin za wojnę wzbudził, zwłaszcza z upływem lat, wiele krytycznych ocen, podkreślających, że owa strusia polityka uniemożliwiła rozliczenie z przeszłością. Historyk James Orr argumentował, że „cesarz, jako górujący nad innymi, potężny symbol tak państwa, jak i narodu, mógł wymusić taką konfrontację publicznie i mocno deklarując swoje poczucie odpowiedzialności oraz stawiając czoło konsekwencjom"93. Dziś wiadomo, że cesarz gotów był na odpowiednią deklarację i omawiał ją ze współpracownikami, głównie z Tajimą. W papierach po tym ostatnim odnaleziono notatkę zawierającą słowa: „Stało się to, ponieważ brakowało nam siły charakteru, wobec tego z głębokim wstydem przepraszamy wszystko pod niebem” (słowo tenka, oddane jako „wszystko pod niebem”, przetłumaczyć można także jako „cały naród” lub ,świat”94). Pochodziła ona jeszcze z 1948 roku, być może więc powstała z myślą o abdykacji. Jednakże nawet projekt przemówienia na 3 maja 1951 roku w swej pierwotnej wersji mieścił zwrot „głęboko przepraszam naród w związku z odpowiedzialnością za klęskę" ${ }^{95}$. Wszystkie plany wyrażenia ekspiacji utrącił wszakże gabinet, skrajnie wąsko rozumiejący zapisany w nowej konstytucji zakaz politycznych wystąpień monarchy.

Jeśli zaś rozliczenie za wojnę było nader niepełne, to winę tę monarcha dzielił z całą japońską klasą polityczną, jeśli nie z całym narodem. Wszystko bowiem wskazuje, że rację miał krytyk filmowy Satō Tadao, mówiąc w 1959 roku: „Dlaczego naród japoński nie próbował podnieść kwestii wojennej odpowiedzialności cesarza? Sądzę, iż dlatego, że dla ogromnej większości rozgrzeszenie cesarza było najłatwiejszym sposobem własnego rozgrzeszenia za wojnę" ${ }^{\prime \prime}$.

\section{BIBLIOGRAFIA}

\section{Archiwalia}

FO 371 General Correspondence

FO 410 Confidential Prints. Japan

WO 203 War Office Papers

The National Archives, London, England

93 J. Orr, The Victim as Hero. Ideologies of Peace and National Identity in Postwar Japan, Honolulu 2001, s. 34.

94 Cyt. za: D. Britton, Prince and Princess Chichibu [w:] H. Cortazzi, Britain \& Japan, vol. V, Folkestone 2005, s. 518.

95 N. Kawamura, op. cit., s. 190.

96 Cyt. za: K.J. Ruoff, The People's Emperor. Democracy and the Japanese Monarchy, 1945-1995, Cambridge, Mass. 2001, s. 136. 


\section{Źródła drukowane}

Foreign Relations of the United States 1945, vol. VI, Washington 1969.

Foreign Relations of the United States 1946, vol. VIII, Washington 1971.

Political Reorientation of Japan. September 1945 to September 1948, by the Supreme Commander of Allied Powers, Government Section, 1949, vols I-II, Westport Conn. 1970.

\section{Pamiętniki}

Craigie R., Behind the Japanese Mask, London 1946.

Emmerson J.K., Japanese Thread. A Life in U.S. Foreign Service, New York 1978.

Sansom K., Sir George Sansom and Japan. Memoir, Tallahassee, Florida 1972.

Sebald W.J., With MacArthur in Japan. A Personal History of Occupation, London 1965.

Vining E.G., Quiet Pilgrimage, Philadelphia 1970.

Vining E.G., Windows for the Crown Prince. Akihito of Japan, Boston 2000.

Willoughby Ch.A., Chamberlain J., MacArthur 1941-1945. Victory in the Pacific, Melbourne 1956.

Yoshida S., The Yoshida Memoirs, Cambridge, Mass. 1962.

\section{Monografie, rozprawy, artykuły}

The American Military and the Far East, ed. J.C. Dix on, Colorado Springs 1980.

Bix H.P., Hirohito and the Making of Modern Japan, New York 2000.

Brines R., MacArthur's Japan, New York-Philadelphia 1948.

Britain \& Japan, ed. H. Cortazzi, vol. V, Folkestone 2005.

Britain \& Japan. Biographical Portraits, ed. I. Nish, Folkestone, Kent 1997.

Britain and Japan, 1859-1991. Themes and Personalities, eds. H. Cortazzi, G. Daniels, London-New York 1991.

Britton D., Prince and Princess Chichibu [w:] Britain \& Japan, ed. H. Cortazzi, vol. V, Folkestone 2005, s. 23-32.

Butow R.J.C., Japan's Decision to Surrender, Stanford, Calif. 1954.

Democratizing Japan. The Allied Occupation, eds. R.E. Ward, Y. Sakamoto, Honolulu 1987.

Finn R.B., Winners of Peace. MacArthur, Yoshida and Postwar Japan, Berkeley 1992.

Fukuda H., The Peaceful Overture: admiral Yamanashi Katsunoshin [w:] Britain and Japan, 1859-1991. Themes and Personalities, eds. H. Cortazzi, G. Daniels, LondonNew York 1991, s. 198-213.

Góralski W., Stany Zjednoczone - Japonia 1945-1972, Warszawa 1976.

Hata I., Hirohito. The Shōwa Emperor in War and Peace, Folkestone 2007.

Hata I., The Occupation of Japan, 1945-1952 [w:] The American Military and the Far East, ed. J.C. Dixon, Colorado Springs 1980, s. 92-101.

Hellegers D.M., The Konoye Affair [w:] The Occupation of Japan. Impact of Legal Reform, ed. L.H. Redford, Norfolk 1978, s. 168-175. 
Hirakawa S., R.H. Blyth and Hirohito's Denial of the Divine Character of the Tennō, „British Association for Japanese Studies. Proceedings" 1985, s. 1-33.

James D.C., The Years of MacArthur, vol. II: 1941-1945, Boston 1975; vol. III: Triumph and Disaster, 1945-1964, Boston 1985.

Kawamura N., Emperor Hirohito and the Pacific War, Seattle-London 2015.

Large S.S., Emperor Hirohito and Shōwa Japan. A Political Biography, London-New York 1992.

Matsumoto K., Shōji J., Critiquing Herbert Bix's “Hirohito”, „Japan Echo” 2002, vol. XXIX, No. 6 (December), s. 64-68.

Nish I., Crown Prince Hirohito in Britain, May 1921 [w:] Britain \& Japan. Biographical Portraits, ed. I. Nish, Folkestone, Kent 1997, s. 205-215.

The Occupation of Japan. Impact of Legal Reform, ed. L.H. Redford, Norfolk 1978.

Od Port Artur do Port Stanley. Z dziejów konfliktów morskich wXX stuleciu, red. R. Kochanowski, J. Jastrzębski, Oświęcim 2016.

Oka Y., Konoe Fumimaro. A Political Biography, Lanham 1992.

Okubo G., The Problem of the Emperor System in Postwar Japan, Tokyo 1948.

Orr J., The Victim as Hero. Ideologies of Peace and National Identity in Postwar Japan, Honolulu 2001.

Pałasz-Rutkowska E., Cesarz Meiji. (1852-1912). Wizerunek władcy w zmodernizowanej Japonii, Warszawa 2012.

Polit J., Admirat Hirohito i Wielka Brytania [w:] Od Port Artur do Port Stanley. Z dziejów konfliktów morskich wXX stuleciu, red. R. Kochanowski, J. Jastrzębski, Oświęcim 2016, s. 125-142.

Polit J., Lew i smok. Wielka Brytania a kryzys chiński 1925-1928, Kraków 2006.

Polit J., Pod wiatr. Czang Kaj-szek 1887-1975, Kraków 2008.

Ruoff K.J., The People's Emperor. Democracy and the Japanese Monarchy, 1945-1995, Cambridge, Mass. 2001.

Schaller M., The American Occupation of Japan. The Origins of Cold War in Asia, New York 1985.

Schaller M., Douglas MacArthur. The Far Eastern General, Oxford 1989.

Shillony B.-A., The Collected Writings of Ben-Ami Shillony, Tokyo 2000.

Shillony B.-A., Divinity and Gender: The Riddle of Japanese Emperors [w:] idem, The Collected Writings of Ben-Ami Shillony, Tokyo 2000, s. 23-36.

Shillony B.-A., The Enigma of the Emperors. Sacred Subservience in Japanese History, Folkestone 2005.

Shillony B.-A., Prince Chichibu and the February 1936 Rebellion, „Princeton Papers in East Asian Studies” 1972, No. 1 (August), s. 123-144.

Starecka K., Geneza systemu cesarza-symbolu [w:] Z chryzantema w herbie. W 10. rocznice wizyty ich Cesarskich Mości, Cesarza i Cesarzowej Japonii na Uniwersytecie Warszawskim, red. U. Mach-Bryson, A. Zalewska, Warszawa 2014, s. 49-92.

Starecka K., Kontrowersje dotyczace prawa ex post facto $w$ świetle Międzynarodowego Trybunału Wojskowego dla Dalekiego Wschodu, ,Japonica” 1995, nr 4, s. 66-74.

Takeda K., The Dual Image of Japanese Emperor, London 1988.

Taylor A.J.P., The War Lords, London 1979.

Ward R.E., Presurrender Planning: Treatment of the Emperor and Constitutional Changes [w:] Democratizing Japan. The Allied Occupation, eds. R.E. Ward, Y. Sakamoto, Honolulu 1987, s. 1-41.

Z chryzantema w herbie. W 10. rocznice wizyty ich Cesarskich Mości, Cesarza i Cesarzowej Japonii na Uniwersytecie Warszawskim, red. U. Mach-Bryson, A. Zalewska, Warszawa 2014. 